\title{
Influence of Vanadium Oxidation States on the Performance of V-Mg-Al Mixed-Oxide Catalysts for the Oxidative Dehydrogenation of Propane
}

\author{
Leticia Schacht, ${ }^{a}$ Juan Navarrete, ${ }^{\mathrm{b}}$ Persi Schacht, ${ }^{* \mathrm{~b}}$ and Marco A. Ramírez ${ }^{\mathrm{b}}$
}

a Instituto Politécnico Nacional. Departamento de Ciencia de Materiales, Escuela Superior de Física y Matemáticas. Av. IPN s/n. Edificio 9 1er. Piso. C.P. O7738

b Instituto Mexicano del Petróleo. Programa de Ingeniería Molecular. Eje Central Lázaro Cárdenas 152 CP. 07730 México D. F., E-mail: pschacha@imp.mx

Received September 22, 2009; accepted February 11, 2010

\begin{abstract}
V-Mg-Al mixed-oxide catalysts for oxidative dehydrogenation of propane were prepared by thermal decomposition of $\mathrm{Mg}$-Al-layered double hydroxides with vanadium interlayer doping. The obtained catalysts were tested for the oxidative dehydrogenation of propane, obtaining good results in catalytic activity (conversion $16.55 \%$ and selectivity $99.97 \%$ ). Results indicated that catalytic performance of these materials depends on how vanadium is integrated in the layered structure, which is determined by the $\mathrm{Mg} / \mathrm{Al}$ ratio. Vanadium interlayer doping modifies the oxidation state of vanadium and consequently catalytic properties. Surface properties were studied by X-ray photoelectron spectroscopic and diffuse reflectance, UV-visible spectroscopy, and temperature programmed reduction (TPR). The analyses provided information about the oxidation state, before and after the reaction. From these results, it is suggested that selectivity to propylene and catalytic activity depend mainly on vanadium oxidation state.

Keywords: V-Mg-Al mixed-oxide, vanadium oxidation XPS, Diffuse reflectance UV-visible spectroscopy, Oxidative Dehydrogenation of propane.
\end{abstract}

\section{Introduction}

Over the last years, the increasing propene demand has impulsed the necessity for alternative ways to produce propene or propene-rich mixtures. Catalytic oxidative dehydrogenation of propane is an optional way to produce propene $[1,2]$.

Most catalysts described in the literature are based on vanadium oxides as the active component $[3,4]$. In particular, vanadium-magnesium mixed oxide $(\mathrm{VMgO})$ catalysts have been reported to exhibit a promising propene yield $[5,6]$.

$\mathrm{V} / \mathrm{Al}_{2} \mathrm{O}_{3}$ catalytic systems also have been studied, producing good results [7-9]. The acidic/basic nature, as well as the redox character, are the most important factors affecting the performance of selective oxidation catalysts [10]. Current investigation is focused on the examination of oxidation and reduction processes that take place on the catalyst surface [11]. Highly dispersed $\mathrm{V}^{5+}$ in a tetrahedral environment has been proposed as the selective site, however, the nature of active and selective sites and some other characteristics of catalysts (acid-base, redox, promoters, etc.) could have a significant effect as well. Thus, it has been suggested that the acid-base character of catalysts could influence the selectivity-determining step, which is probably related to the adsorption/desorption of olefin intermediates and reaction products [12].
Resumen. Se prepararon mezclas de óxidos de V-Mg-Al como catalizadores en la reacción de deshidrogenación oxidativa de propano. Los catalizadores se obtuvieron a partir de la descomposición térmica de hidróxidos $\mathrm{Mg}$-Al de doble capa y modificados con vanadio en la intercapa. El comportamiento catalítico depende de la manera de incorporación del vanadio dentro de la estructura, la cual esta definida por la relación $\mathrm{Mg} / \mathrm{Al}$. Los resultados obtenidos muestran que la relación $\mathrm{Mg} / \mathrm{AL}$ determina la forma de incorporación y el estado de oxidación del vanadio en la estructura. Las propiedades superficiales se estudiaron por medio de espectroscopia fotoelectrónica de rayos $\mathrm{X}$, espectroscopia UV-visible y temperatura programada de reducción. La información obtenida de estos análisis permitió establecer los estados de oxidación del vanadio antes y después de la reacción química. De acuerdo con estos resultados, se sugiere que la selectividad hacia propeno depende del estado de oxidación del vanadio en el catalizador.

Palabras clave: Óxidos de V-Mg-Al, oxidación del vanadio, XPS, refractancia difusa, espectroscopia UV-visible, deshidrogenación oxidativa de propano.

The formal valence state of vanadium in different vanadium-based systems varies between $\mathrm{V}^{5+}\left(\mathrm{V}_{2} \mathrm{O}_{5}, \mathrm{VOPO}_{4}\right.$, magnesium vanadate, $\mathrm{VO}_{4}$, tetrahedral and $\mathrm{VO}_{6}$ octahedral on $\mathrm{MgO}$, hydrotalcites, sepiolite and $\mathrm{Al}_{2} \mathrm{O}_{3}$ ), $\mathrm{V}^{+4}$ (vanadyl pyrophosphate, solid solutions of $\mathrm{MoO}^{3}$ in $\mathrm{V}_{2} \mathrm{O}_{5}$ ), and the $\mathrm{V}^{3+}$ and $\mathrm{V}^{4+}$ mixture in vanadium antimonite [13].

It has been indicated that the appearance and relative proportions of different phases in Mg-V-O or Al-V-O systems depend to a large extent on the method of catalyst preparation [14]. This prompted in some cases to employ synthetic procedures used for the preparation of layered double hydroxides to obtain precursors of potentially active mixed-oxide systems. Layered double hydroxides, known also as hydrotalcites or anionic clays, consist of brucite $\left\{\mathrm{Mg}(\mathrm{OH})_{2}\right\}$-like layers with part of the divalent cations substituted by trivalent ones. For this reason, the layers acquire excess positive charge, compensated by the incorporation of hydrated anions in the interlayer space.

Their general formula is given as $\left\{\mathrm{M}(\mathrm{II})_{1-\mathrm{x}} \mathrm{M}(\mathrm{III})_{\mathrm{x}}\right.$ $\left.(\mathrm{OH})_{2}\right\} \mathrm{A}_{\mathrm{x} / \mathrm{n}}{ }^{\mathrm{n}-} \cdot \mathrm{mH}_{2} \mathrm{O}$, where $\mathrm{M}(\mathrm{II})$ and $\mathrm{M}(\mathrm{III})$ are the layer forming cations and $\mathrm{A}^{\mathrm{n}-}$ is the interlayer anion. Due to the homogeneous distribution of $\mathrm{M}(\mathrm{II})$ and $\mathrm{M}(\mathrm{III})$ in the layered double hydroxides framework and the layered structure, during thermal decomposition these materials yield mixed oxides of both cations with unique surface and catalytic properties [15-18]. 
The aim of this paper is to determine the influence of different vanadium oxidation states $\mathrm{V}-\mathrm{Mg}$ - $\mathrm{Al}$ mixed-oxide catalysts, on the performance of propane oxidative dehydrogenation. To achieve this, Mg-Al-layered double hydroxides were prepared with vanadium interlayer doping, and by varying $\mathrm{Mg} / \mathrm{Al}$ ratio different valence state of vanadium were obtained,

\section{Results and Discussion}

X-ray photoelectron spectroscopy (XPS). Figure 1 shows the spectra of the hydrotalcites modified with vanadates before catalytic activity. Each spectrum exhibits two peaks that are characteristic of structure of vanadium $\left(2 \mathrm{p}_{3 / 2}, 2 \mathrm{p}_{1 / 2}\right)$, corresponding to a spin orbital with specific binding energies. The spectra of sample M2AV-27.3 with $\mathrm{Mg} / \mathrm{Al}=2$ has one peak at $514.9 \mathrm{eV}$, corresponding to $\mathrm{V} 2 \mathrm{p}_{3 / 2}$, and another at $522.5 \mathrm{eV}$, corresponding to $\mathrm{V} 2 \mathrm{p}_{1 / 2}$. These values represent $\mathrm{V}_{2} \mathrm{O}_{4}$ species with a $\mathrm{V}^{4+}$ oxidation state. In samples M3AV-26.2 and M3AV$22.5(\mathrm{Mg} / \mathrm{Al}=3)$, one peak is at $516.4 \mathrm{eV}$, corresponding to $\mathrm{V} 2 \mathrm{p}_{3 / 2}$, and the other one at $523.5 \mathrm{eV}$, corresponding to $\mathrm{V} 2 \mathrm{p}_{1 / 2}$. The latter is characteristic of $\mathrm{V}_{2} \mathrm{O}_{5}$ species with a $\mathrm{V}^{5+}$ oxidation state. Finally, sample M4AV-25.1 $(\mathrm{Mg} / \mathrm{Al}=4)$ exhibits a peak at $516.5 \mathrm{eV}$, corresponding to $\mathrm{V} 2 \mathrm{p}_{3 / 2},\left(\mathrm{~V}^{5+}\right.$ oxidation state) and a second one at $512.4 \mathrm{eV}$, reported for free $\mathrm{V}$ [19].

Thus, the structure and oxidation state depend on $\mathrm{Mg} / \mathrm{Al}$ ratio of the synthesized hydrotalcites.

Figure 2 shows the XPS spectra of the synthesized hydrotalcites after the catalytic tests. The spectrum of the samples shows two characteristic peaks of the of vanadium structure $\left(2 p_{3 / 2}, 2 p_{1 / 2}\right)$, corresponding to spin orbital with binding energies located between 515.3 and $522.8 \mathrm{eV}$ for all catalytsts. These values of $\mathrm{BE}$ represent $\mathrm{V}_{2} \mathrm{O}_{3}$ species with a $\mathrm{V}^{3+}$ oxidation state.

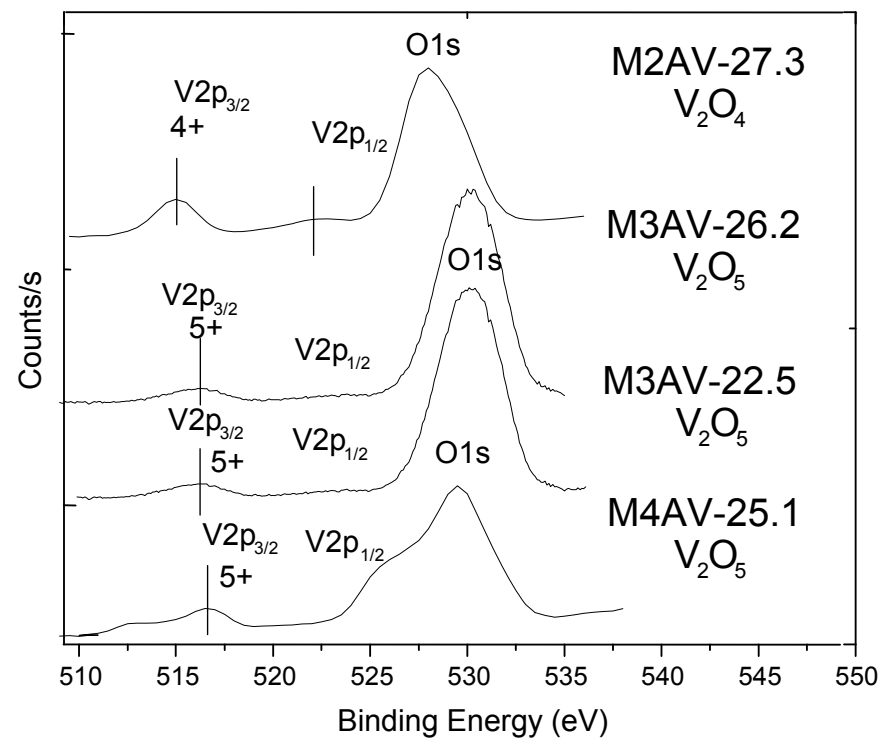

Fig. 1. XPS spectra of catalysts M2AV-27.3, M3AV-26.2, M3AV-22.5 and M4AV-25.1 before catalytic activity.
$\mathrm{H}_{2}$-TPR studies were carried out in order to clarify the vanadium oxidation states. As it can be seen in Figure 3, temperature programmed reduction profiles of all analyzed catalysts show a reduction peak around $808 \mathrm{~K}$, related to consumption of $\mathrm{H}_{2}$, attributed to the change of $\mathrm{V}^{5+}$ to $\mathrm{V}^{4+}$ as the first step in the reduction of vanadium pentoxide as it has been reported [17].

By this way, $\mathrm{H}_{2}$-TPR results support the assignation of vanadium states using XPS spectroscopy.

Diffuse reflectance UV-vis spectra of the samples, before and after of catalytic activity, are presented in Figures 5 and 6, respectively. The intensity of the absorption edge decreases at lower average $\mathrm{V}$ oxidation states because the ligand-to-metal charge transfer becomes more difficult at lower cation valences where the lowest unoccupied states are partially filled and thus require electron transfer to a lower energy state [18]. From figure 4, it can be observed that M2AV-27.3 catalyst exhibits

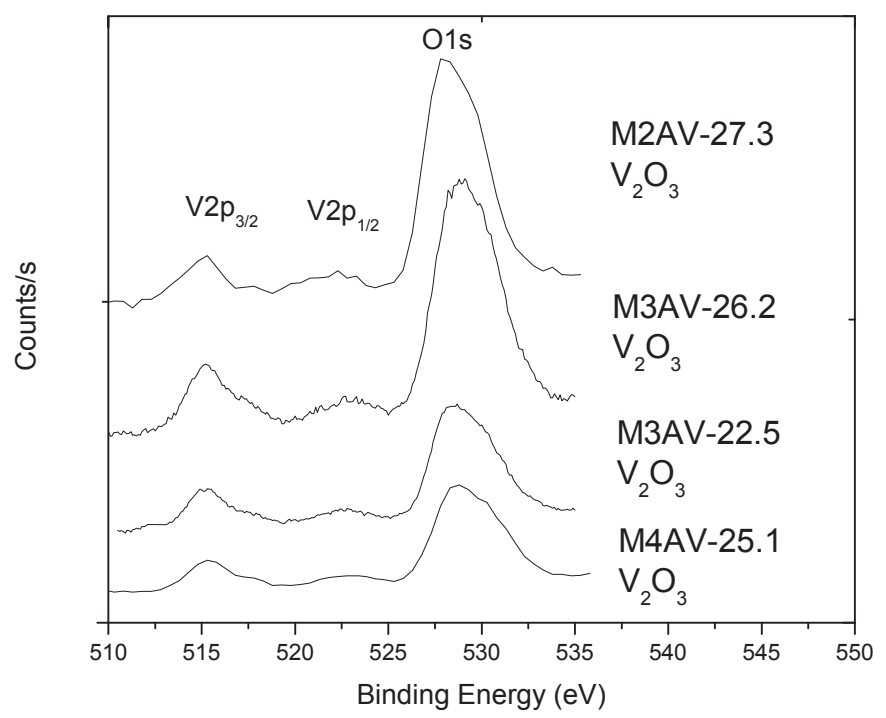

Fig. 2. XPS spectra of catalysts M2AV-27.3, M3AV-26.2, M3AV-22.5 and M4AV-25.1 after catalytic activity.

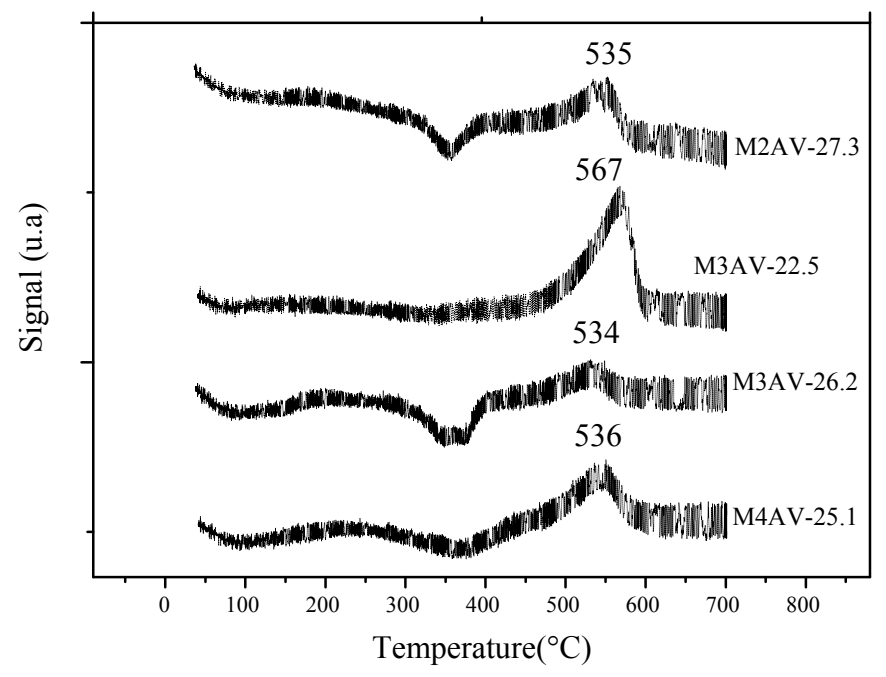

Fig. 3. TPR spectra of catalysts M2AV-27.3, M3AV-26.2, M3AV-22.5 and M4AV-25.1 
a band at $3.6 \mathrm{eV}$, corresponding to $\mathrm{V}^{4+}$, for $\mathrm{M} 3 \mathrm{AV}-26.2$ and $\mathrm{M} 3 \mathrm{AV}-22.5$ catalysts there is band at $4.3 \mathrm{eV}$, corresponding to $\mathrm{V}^{5+}$, and finally for M4AV-25.1 the band is located at $3.6 \mathrm{eV}$, corresponding to $\mathrm{V}^{4}$ and $\mathrm{V}^{5+}$ [18-21].

Figure 5 Shows that for the samples the band is located at $4.1 \mathrm{eV}$, corresponding to $\mathrm{V}^{3+}$.

\section{Catalytic activity studies}

The catalysts obtained after calcination at $700{ }^{\circ} \mathrm{C}$ were tested for oxidative dehydrogenation of propane in a $673-813 \mathrm{~K}$ temperature range.

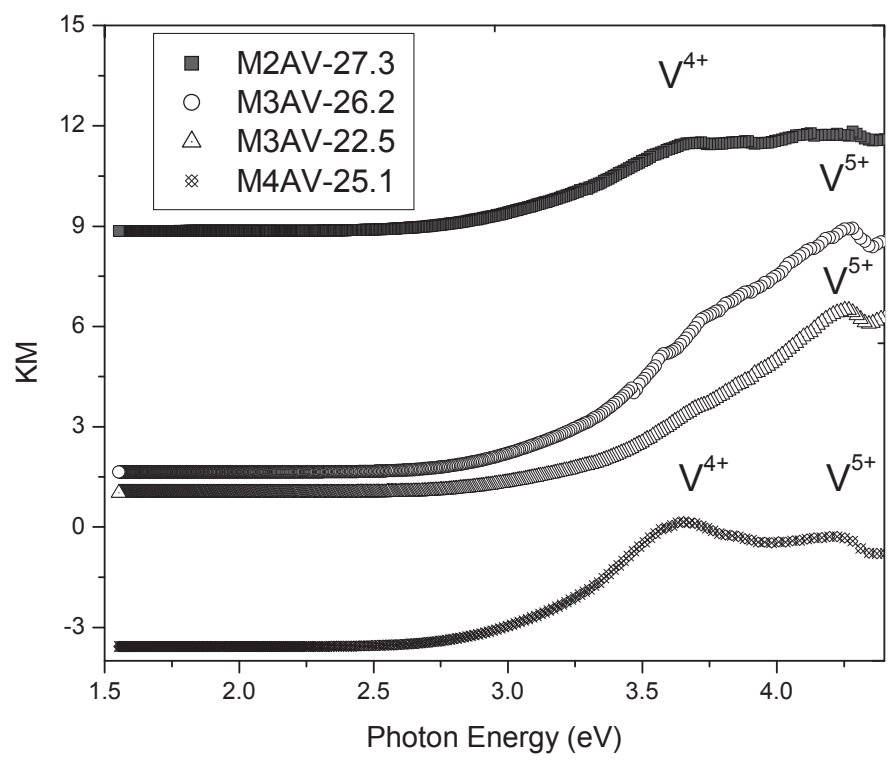

Fig. 4. UV-vis spectra of catalysts before oxidative dehydrogenation of propane.

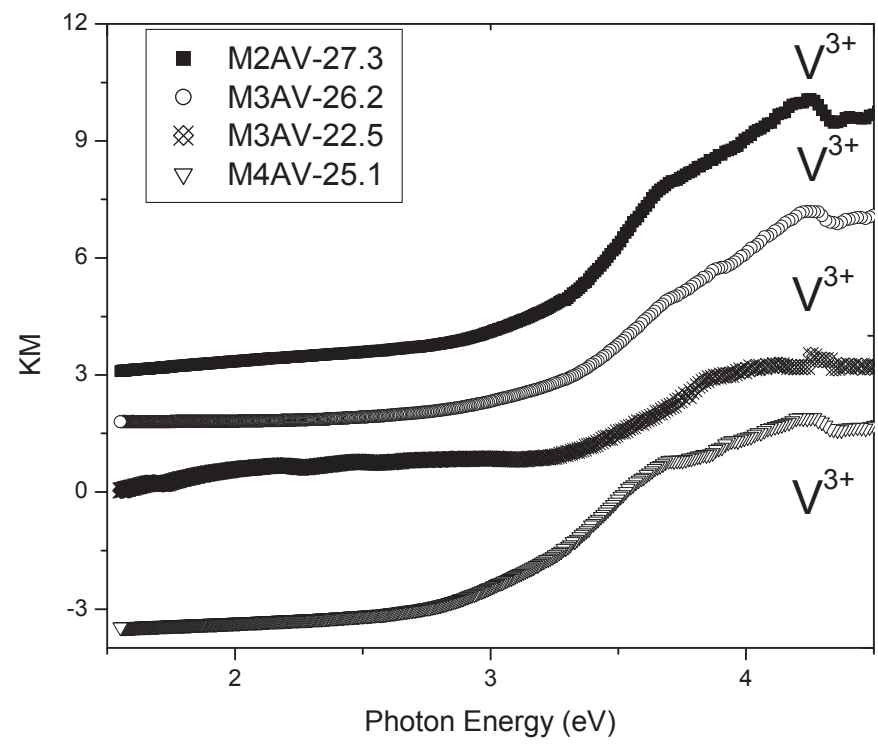

Fig. 5. UV-vis spectra of catalysts after oxidative dehidrogenation of propane.
Figs. 6 and 7 show the effect of reaction temperature on propane conversion and selectivity, respectively. The highest propane conversion and selectivity to propene at $693 \mathrm{~K}$ was achieved by $\mathrm{M} 3 \mathrm{AV}-26.2$ catalyst with $\mathrm{Mg} / \mathrm{Al}=3$ and vanadium concentration of $26.2 \%$ (Conversion $21 \%$ and Selectivity $99.97 \%$ ). Nevertheless, good results were also produced by $\mathrm{M} 3 \mathrm{AV}-22.5$ catalyst with $\mathrm{Mg} / \mathrm{Al}=3$ and vanadium concentration of $22.5 \%$, (Conversion $16.6 \%$ and Selectivity $99.6 \%$ ) between 713 and $813 \mathrm{~K}$.

XPS spectra provide insight on the structure and oxidation state in the catalysts surface, which was identified to depend on $\mathrm{Mg} / \mathrm{Al}$ ratio. Diffuse reflectance UV-vis analyses confirm XPS results on the oxidation state of vanadium. This is useful for establishing the relationship between catalyst activity and structure.

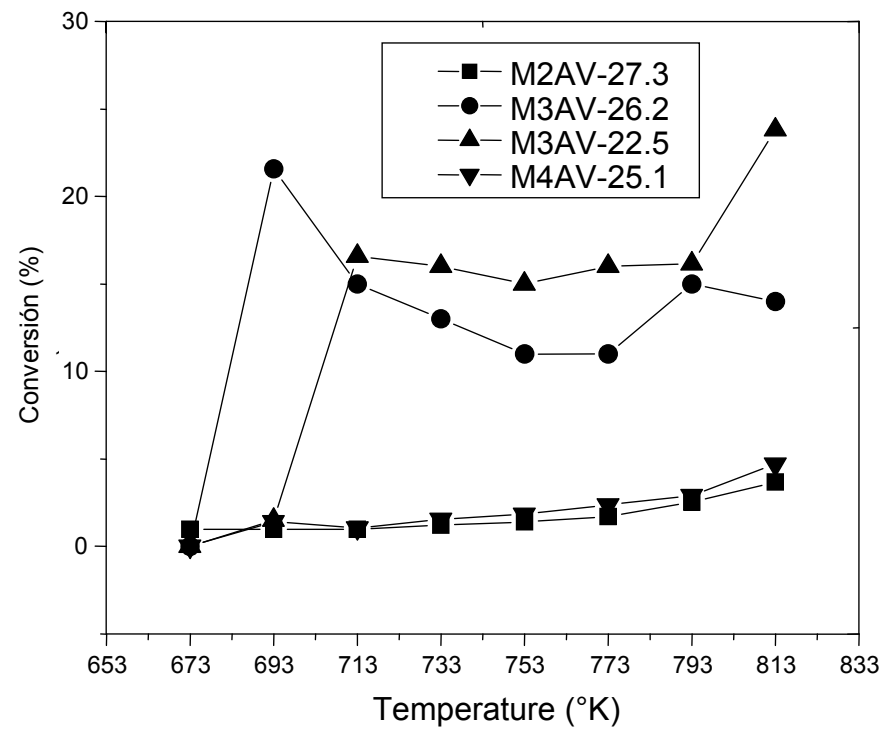

Fig. 6. Propane conversion as function of reaction temperature

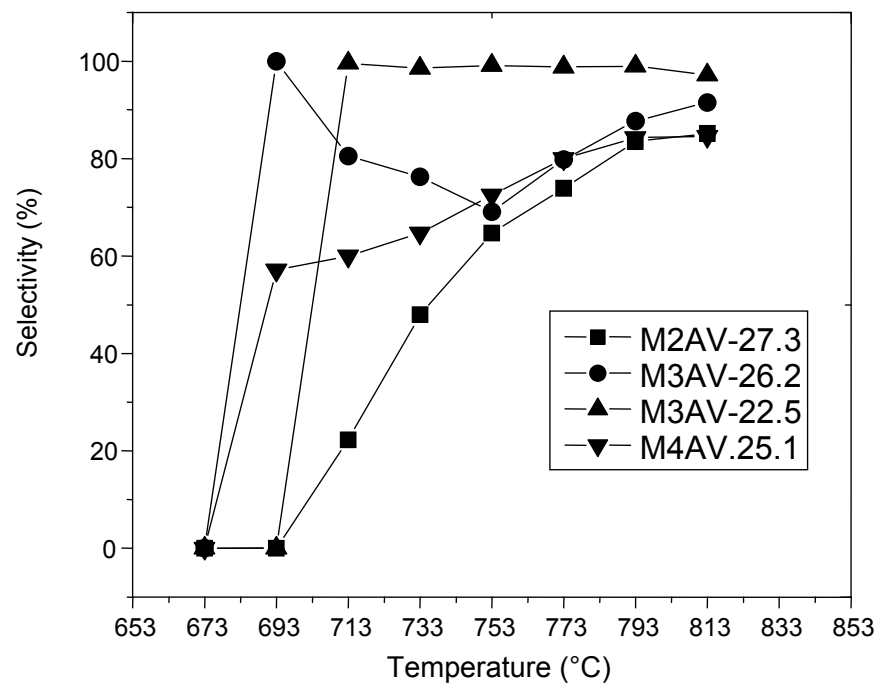

Fig. 7. Propane selectivity to propene as function of reaction temperature 
M3AV-26.2 and M3AV-22.5 catalysts provided much higher performances during the oxidative dehydrogenation of propane, particularly the selectivity to propene (99.97\%), which is probably caused by the $\mathrm{V}_{2} \mathrm{O}_{5}$ structure.

The observed activity for these catalysts might be related to the reducibility of surface $\mathrm{V}^{5+}$ species.

\section{Conclusions}

In summary, the present study demonstrates that the combination of XPS and diffuse reflectance UV-vis spectroscopy provides important information on the oxidation states and active surface sites of catalyst used for the oxidative dehydrogenation of propane.

The acidic and basic nature, as well as the redox character, are the most important factors affecting the performance of selective oxidation catalysts.

The acid-base character of hydrotalcites modified with vanadates, containing $\mathrm{Al}$ and $\mathrm{Mg}$ and calcined at $973 \mathrm{~K}$, determined the reducibility of vanadium species and consequently the activity of these catalysts.

\section{Experimental}

\section{Catalysts preparation}

Vanadium-magnesium-aluminum mixed-oxide catalysts (V$\mathrm{Mg}-\mathrm{Al}-\mathrm{O})$ (hydrotalcite) were prepared by coprecipitation. About $200 \mathrm{~mL}$ of decarbonated and deionized water were put in a one liter round-neck flask, filled with nitrogen, and stirred keeping temperature at about $30^{\circ} \mathrm{C}$. An aqueous solution of $\mathrm{Mg}\left(\mathrm{NO}_{3}\right)_{2} \cdot 6 \mathrm{H}_{2} \mathrm{O}$ and $\mathrm{Al}\left(\mathrm{NO}_{3}\right)_{3} \cdot 9 \mathrm{H}_{2} \mathrm{O}$ (sample $\mathrm{Mg} / \mathrm{Al}=2$ : $\mathrm{Mg}^{2+}=0.50 \mathrm{~mol} / \mathrm{L}, \mathrm{Al}^{3+}=0.25 \mathrm{~mol} / \mathrm{L}$ ); (sample $\mathrm{Mg} / \mathrm{Al}=3$ : $\left.\mathrm{Mg}^{2+}=0.75 \mathrm{~mol} / \mathrm{L}, \mathrm{Al}^{3+}=0.25 \mathrm{~mol} / \mathrm{L}\right) ;($ sample $\mathrm{Mg} / \mathrm{Al}=4$ : $\mathrm{Mg}^{2+}=1.0 \mathrm{~mol} / \mathrm{L}, \mathrm{Al}^{3+}=0.25 \mathrm{~mol} / \mathrm{L}$ ) was added dropwise, keeping $\mathrm{pH}$ of the reacting mixture at 10 by dropwise addition of $\mathrm{NaOH}$ solution $(2 \mathrm{~mol} / \mathrm{L})$. The resulting white slurry was stirred for $24 \mathrm{~h}$. The obtained precipitate was filtered, washed with water and dried at $80{ }^{\circ} \mathrm{C}$ for $48 \mathrm{~h}$.

\section{Procedure of Anion Exchange (Pillars)}

The exchange of $\mathrm{NO}_{3}{ }^{-}$to $\mathrm{VO}_{3}{ }^{-}$anions was performed by contacting the hydrotalcite with a solution of ammonium metavanadate. A first solution containing $60 \mathrm{~g}$ of hydrotalcite dispersed in $100 \mathrm{~mL}$ of deionized and decarbonated water, and a second one consisting of $2.4 \mathrm{~g}$ of $\mathrm{NH}_{4} \mathrm{VO}_{3}$ dissolved in $50 \mathrm{~mL}$ of water, were mixed and stirred at $333 \mathrm{~K}$ for $1 \mathrm{~h}$. After filtration, the solids were washed and dried at $393 \mathrm{~K}$ for $24 \mathrm{~h}$. The obtained solids were treated at $973 \mathrm{~K}$ for $6 \mathrm{~h}$ (samples: M2AV-27.3, M3AV-26.2, M3AV-22.5 and M3AV-25.1).

\section{Characterization}

The X-ray photoelectron spectroscopic (XPS) analyses were carried out with a ESCALAB 250 spectrometer using a monochromatic Al-k $\alpha \mathrm{X}$-ray source. Binding energy (BE) scale was referenced to the $\mathrm{C} 1 s$ line peak at $284.8 \mathrm{eV}$, originated from adventitious carbon contamination, to account for charging effects [16].

The Temperature programmed reduction (TPR) analyses was carried out in a Micromeritics TPD/TPR 2900 apparatus consisting of a quartz U- reactor using $10 \% \mathrm{H}_{2}$ in argon and heating rate of $283 \mathrm{~K} / \mathrm{min}$. The samples were pretreated in flowing $\mathrm{N}_{2}(99.99 \%)$ at $723 \mathrm{~K}$ for $0.5 \mathrm{~h}$ and cooled in $\mathrm{N}_{2}$. During the reduction, samples were heated from 50 to 1173 $\mathrm{K}$.

Diffuse reflectance UV-vis analyses, in the range of 2-6 $\mathrm{eV}$, were performed employing a Perkin Elmer Lambda 900 spectrophotometer with a diffuse reflectance attachment, using $\mathrm{MgO}$ as reference. Spectra of catalysts were collected under ambient conditions and analyzed with the Kubelka-Munk treatments $[17,18]$.

\section{Catalytic Activity}

Catalytic tests were carried out at atmospheric pressure in a fixed-bed tubular flow quartz reactor (internal diameter $=5$ $\mathrm{mm}$ and operation length $=21 \mathrm{~cm})$. A small amount $(0.1 \mathrm{~g})$ of catalysts was loaded in the midsection of the reactor, and above the catalyst bed quartz granules were loaded to quench the possible homogeneous reactions. The reactor was pretreated at $573 \mathrm{~K}$ for 1 hour $30 \mathrm{~min}$, passing continuously an oxygen-nitrogen mixture with molar composition of 1:3.762. After pretreatment, the reactor was heated from 573 to $673 \mathrm{~K}$, a feed mixture composed of propane-oxygen (1:1) and oxygennitrogen (1:3.762) was passed through the reactor. Initiation of catalytic tests was carried out in the 673-813 K temperature range. Analysis of reactants and products was carried out with a Perkin Elmer Autosystem XL gas chromatograph.

\section{Acknowledgements}

Authors thank CONACYT, IMP, CIMAV and IPN for the financial support.

\section{References}

1. Jibrila, B. Y.; Al-Zahrania, S. M.; Abasaeeda, A. E.; Hughesb, R. J. Chem. Eng. 2004, 103, 59-67.

2. López Nieto, J. M. Topic in Catalysis. 2006, 41, 3-9.

3. Dai, G. L.; Liu, Z. P.; Wang, W. N.; Lu, J.; Fan, K. N. J. Phys. Chem C. 2008, 112, 3719-3725.

4. Fu, H.; Liu, Z. P.; Li, Z. H.; Wang, W. N.; Fan, K. N. J. Am. Chem. Soc. 2006, 128, 11114-11123. 
5. Concepcion, P.; Navarro, M. T.; Blasco, T.; López Nieto, J. M.; Panzacchi1, B.; Rey, F. Catal. Today 2004, 96, 179-186.

6. Solsona, B.; Dejoz, A.; Vázquez, I.; Márquez, F.; López Nieto, J. M. Appl. Catl. A. 2001, 208, 99-110.

7. Prada Silvy, R.; Sergey, P.; Chenakin, B.; Bastin, J. M.; Kruse, N.; Barbero, P.; Cadús; L. Appl. Catal. A. 2004, 263, 163-170.

8. Menendez, M.; Santamaria, J. Chem. Eng. SCI, 1999, 54, 12651272.

9. Bottino, A.; Capannelli, G.; Comite, A.; Storace, S.; Renzo Di Felice, R. Chem. Eng. J. 2003, 94, 11-18.

10. López Nieto, J. M.; Soler, J.; Concepción, P.; Herguido, J.; Menendez, M.; Santamaría, J. J. Catal. 1999, 185, 324-332.

11. Lemonidou, A. A.; Nalbandian, L.; Vasalos, I. A. Catal. Today 2000, 61, 333-341.

12. Balderas-Tapia, L.; Wang, J. A.; Hernández-Pérez, I.; AguilarRíos, G.; Schacht, P. Mat. Lett. 2004, 58, 3034-3039.

13. Barbero, B. P.; Cadús, L. E.; Hilaire, L. Appl. Catal. A. 2003, 246, 237-242.
14. Mamedov, E. A.; Cortés Corberán, V. Appl. Catal. A. 1995, 127, $1-40$.

15. Dula, R.; Wciso, K.; Stoch, J.; Grzybowska, B.; Serwicka, E. M.; Kooli, F.; Bahranowski, K.A. Appl. Catal. A. 2002, 230, 281-291.

16. Wagner, Ch. D.; Naumkin, A. V.; Kraut-Vass, A.; Allison, J. W.; Powell, C.; John R. Rumble, J. R. NIST Standard Reference Database 20, 2000, 3.5.

17. Shiju, N. R. Thesis University of Pune, India, 2004.

18. Morris, D. Argyle.; Kaiodong, Chen,; Carlo R.; Catherin, K.; Alexis. T.; Iglesia, E. J. Phys. Chem B. 2004, 108, 2345-2353.

19. Morris, D. Argyle.; Kaiodong, Chen,; Iglesia, E.; Alexis, T. J. Phys. Chem B. 2005, 109, 2414-2421.

20. Barbero, B. P.; Cadús, L. E.; Hilaire, L. Appl. Catal. A. 2003, 246, 237-243.

21. Wu, Z.; Hack-Sung, K.; Stair, P. C.; Rugmini, S.; Jackson, S. D. J. Phys. Chem. B. 2005, 109, 2793-2801. 